\title{
Annual effective dose and air absorbed dose based on airborne and ground gamma-ray spectrometry: Serra do Carambeí and Joaquim Murtinho granites, southern Brazil
}

\author{
Antonelli F. *, LPGA-UFPR; Ferreira FJF, LPGA-UFPR
}

Copyright 2019, SBGf - Sociedade Brasileira de Geofísica

This paper was prepared for presentation during the $16^{\text {th }}$ International Congress of the Brazilian Geophysical Society held in Rio de Janeiro, Brazil, 19-22 August 2019.

Contents of this paper were reviewed by the Technical Committee of the $16^{\text {th }}$ International Congress of the Brazilian Geophysical Society and do not necessarily represent any position of the SBGf, its officers or members. Electronic reproduction or storage of any part of this paper for commercial purposes without the written consent of the Brazilian Geophysical Society is prohibited.

\begin{abstract}
We investigated the air absorbed dose (AAD) and the annual effective dose (AED) of the Serra do Carambeí (CA) and Joaquim Murtinho (JM) granites, based on airborne and ground gamma-ray spectrometry data. Important relationships are considered between each radioelement $\left(\mathrm{K}, \mathrm{U}_{\mathrm{eq}}\right.$ and $\left.\mathrm{Th}_{\mathrm{eq}}\right)$ and the effective dose distribution, with effects of topographic and environmental variations. High values of potassium and uranium and very high values of thorium were confirmed. The mean average of AAD is $100 \%$ (airborne) and $170 \%$ (ground) in CA and $35 \%$ (airborne) $218 \%$ (ground) in JM upper the global mean average. Both granites showed values of AED superior to the recommended by international health organizations. The CA granite revealed approximately twice the safety value in both data types. For the JM granite the values are almost five times (ground data) and about one and a half times greater (airborne data) than those suggested for outdoor exposure.
\end{abstract}

\section{Introduction}

Several epidemiological studies have been designed to assess hazards from exposure to natural radiation (Grastly \& LaMarre 2004, Ye \& Gan 2013, Oatway et al. 2016). A large effort is being made by nations to understand and minimize the consequences of this that, although it is a natural process, it can entail damages to human's health when background radioactivity reaches high levels (US EPA 1993; EC 1999; UNSCEAR 2000).

Radioactivity on Earth is a process that occur constantly and has terrestrial and extraterrestrial origins, being part originated in subsurface by decay of the parent nuclides ${ }^{238} \mathrm{U},{ }^{232} \mathrm{Th}$ and the nuclide ${ }^{40} \mathrm{~K}$. Upon decay, these radionuclides produce an external radiation field to which all individual are exposed being them the principal dose radiation source on earth (UNSCEAR 2000). The measurement of radiation from rocks and soils are made by detection of gamma-rays, that identifies each radioelement through their respective energy spectrum. In this way, we can estimate dose rates, radon concentration and other parameters from readings of $\mathrm{K}(\%)$ and equivalents of $U$ (ppm) and Th (ppm) in rocks and soils up 30-45 cm deep (Dickson \& Scott 1997; Minty 1997; Wilford et al. 1997; IAEA 2003).

The earth's upper crust has about 2-2.5\% of K, 2-3 ppm of $\mathrm{U}$ and 8-12 ppm of Th (Ulbrich et al. 2009). The average of these two radioelements are $15 \mathrm{ppm}$ for Th and $4 \mathrm{ppm}$ for $U$ in igneous rocks with granitic composition. The potassium content is relatively low in granites $(\sim 2.4 \%)$ and higher in felsic volcanic and pegmatites ( 3.7\%). In granites, the concentration of $T h$ and $U$ is higher when compared with basaltic or ultramafic rocks $(<1 \mathrm{ppm}$ and $<$ 8 ppm for U and Th, respectively) (Ulbrich et al. 2009).

The radioactivity on rocks depends on their original composition when formed during the molten. However, the radiometric signature can vary a lot even over the same formation due changes in content of radioelements by small lithological differences, weathering, regolith effects and mineralizing events (Dickson \& Scott 1977). On air, the presence of soil-derived radionuclide will depend of local rocks and soil, wind, and moisture conditions (UNSCEAR 2000).

The global mean value of the dose in air according to the distribution of the population ranges 50-59 nGy $\mathrm{h}^{-1}$ (UNSCEAR 2010, Engola et al. 2018). The detriment per unit of effective dose for public members is $7.310^{-5} \mathrm{mSv}$, being $1000 \mu \mathrm{Sv}$ the limit accepted in a year. Higher values can be considered a hazard by the United States Environmental Protection Agency (US EPA 1993) and by the Organization for Economic Co-operation and Development (EC 1999).

The scope of this work is to estimate the AAD and the AED of the CA and JM granites, based on the airborne and ground measurements of $\mathrm{K}(\%), \mathrm{U}_{\mathrm{eq}}(\mathrm{ppm})$ and $\mathrm{Th}_{\mathrm{eq}}(\mathrm{ppm})$, in order to assess the risks associated to the human health. The results are compared with indices suggested by international medical organizations and radiological institutions.

\section{Study Area and Geology}

Related to Upper Proterozoic and after the collisional events of Brasiliano Cycle, Serra do Carambeí (CA) and Joaquim Murtinho (JM) are two granitic bodies that they're part of the Cunhaporanga Granitic Complex (Guimarães 2000), which are localized in State of Paraná, southern Brazil (Fig. 1). Both are equigranular and fluorite is one of secondary minerals.

The CA granite (e.g. Pinto-Coelho 1986; Guimarães 2000) has an elongated form in NE-SW direction, with $14 \mathrm{~km}$ length and $7.3 \mathrm{~km}$ width (Fig. 1), and it is a biotite alkali feldspar granite with quartz and hematite. Fluorite and zirconium are secondary minerals.

The Joaquim Murtinho granite (CCGP 1970; Guimarães 1995; Guimarães \& Ulbrich 1996) is an igneous intrusion with irregular shape and area $<10 \mathrm{~km}^{2}$ (Fig. 1). It forms a relative local depression, delimitated by sandstones of Furnas Formation in east, north and west, monzogranite in south and alluvial deposits at south-west. It is composed mainly of alkali feldspars, biotite and quartz. The fractures 
are filled with hematite, fluorite and/or sulfides (Mineropar 2006; Ulbrich et al. 2009).

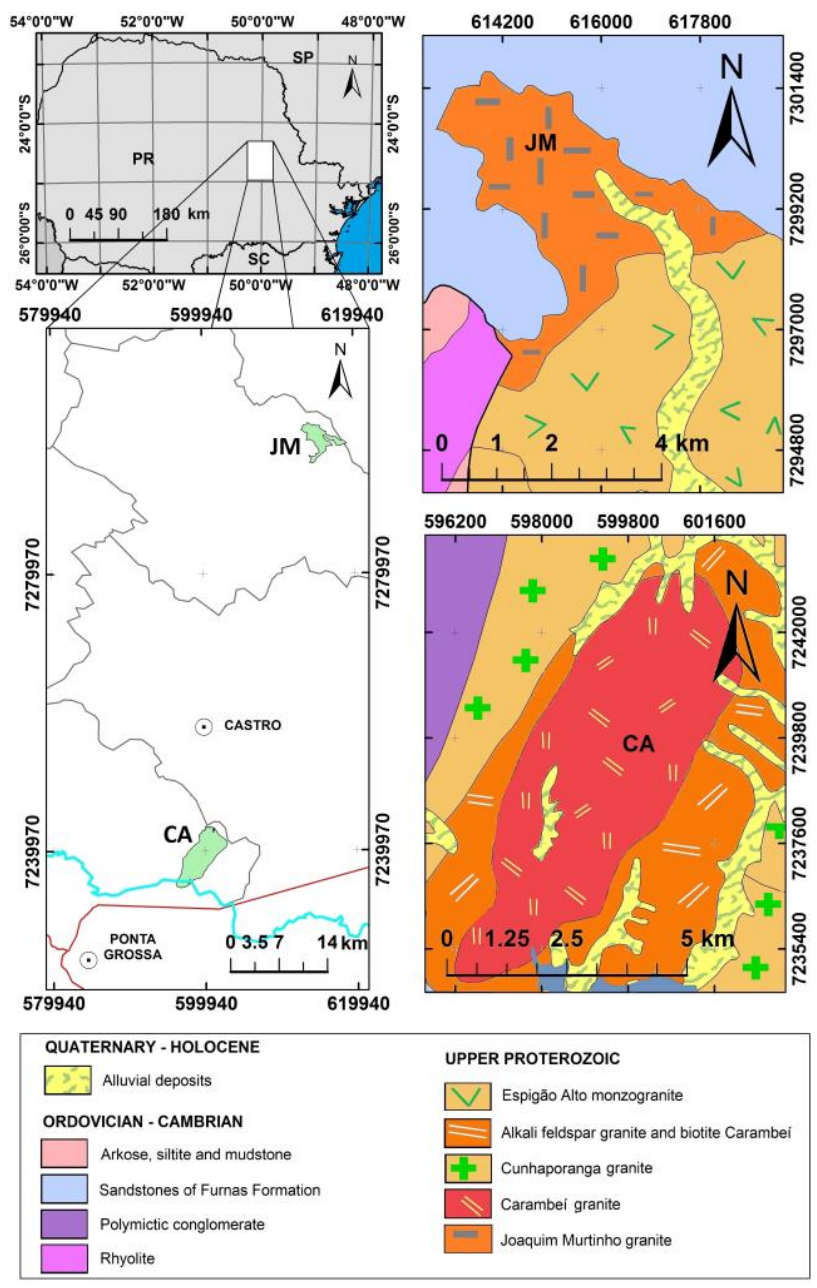

Figure 1 - Location and geological units of the Serra do Carambeí (CA) and Joaquim Murtinho (JM) granites (modified from Mineropar 2006).

\section{Material and Methods}

\section{Data}

We used airborne and ground gamma-ray spectrometry data $\left(\mathrm{K}, \% ; \mathrm{Th}_{\mathrm{eq}}, \mathrm{ppm} ; \mathrm{U}_{\mathrm{eq}}, \mathrm{ppm}\right)$ to estimate the Air Absorbed Dose (AAD) and the Annual Effective Dose radiation (AED) of the Serra do Carambeí (CA) e Joaquim Murtinho (JM) granites. The database comprises 850 readings in the area CA granite: 766 airborne measurement and 84 terrestrial stations. Inside the limits attributed to the JM granite were read 348 points: 310 from airborne survey and 38 measurements on ground (Tables 1 and 2).

The airborne data are from Paraná-Santa Catarina Project (CPRM 2011). The flight lines in NS direction was spacing of $500 \mathrm{~m}$, with a mean terrain clearance of $100 \mathrm{~m}$ and the time interval between the measures was 1 second.

The authors Ferreira et al. (2001) and Fruchting et al. (2003) firstly presented the ground data of the CA and JM granites, respectively. Detailed discussion about the terrestrial data of $\mathrm{JM}$ and CA can be seen in Ferreira et al. (2009) and Godoy et al. (2011), respectively. The ground data was acquired by a GS-512 gamma-ray spectrometer, manufactured by Geofysika from Czech Republic. Tables 1 and 2 and Figure 2 shows, respectively, the basic statistics and the graphs of the CA and JM data.

\section{Radiation doses estimates}

Radiation dose estimates are possible based on the $\mathrm{K}(\%)$, $\mathrm{U}_{\mathrm{eq}}(\mathrm{ppm})$ and $\mathrm{Th}_{\mathrm{eq}}(\mathrm{ppm})$ measurements. The International Atomic Energy Agency (IAEA 1991) and the International Commission on Radioactive Units of Measurements (ICRU 1994) recommended an air absorbed dose (AAD) estimation based on airborne gamma-ray spectrometric surveys (Ye \& Gan 2013, Beamish 2016), according to equation (1):

$\operatorname{AAD}\left(\mathrm{nGy} \mathrm{h}^{-1}\right)=13.078 \mathrm{~K}+5.675 \mathrm{U}_{\mathrm{eq}}+2.496 \mathrm{Th}_{\mathrm{eq}}$

The constants that multiply $\mathrm{K}(\%), \mathrm{U}_{\mathrm{eq}}(\mathrm{ppm})$ and $\mathrm{Th}_{\mathrm{eq}}$ (ppm) in the equation (1) were suggested by IAEA (2010) as default parameters. $1 \mathrm{~Gy}$ is equal to $100 \mathrm{rad}$ or $1 \mathrm{~J} / \mathrm{kg}$.

Dose rate indicates the quantity of radiation absorbed per unit of time. A similar measurement is radiation dose, which refers to the rate with which a person has been exposed to a radiation source.

The sum of multiples of equivalent doses in human organs is measured by the effective dose, where each organ has a specific weighting factor. The adopted form to evaluate the contribution of natural radionuclides only from soil, rocks and manufactured materials during a year, excluding extraterrestrial radiation, is the annual effective dose radiation (AED). AED quantifies the biological and medical effects associated with the type of ionizing radiation during a year (Ray \& Stick 2015, Beamish 2016). Godoy et al. (2011) proposed the equation (2) based on Grasty et al. (1984).

$$
\mathrm{AED}=320+52.6\left(1.505 \mathrm{~K}+0.625 \mathrm{U}_{\mathrm{eq}}+0.310 \mathrm{Th}_{\mathrm{eq}}\right)(
$$

The SI unit adopted by IAEA (2003) is the micro Sieverts per year $\left(\mu S v y^{-1}\right)$, the most used for studies that connect radiation effects in human body.

The AED expression considers the contribution of $\mathrm{K}, \mathrm{U}_{\mathrm{eq}}$ and $\mathrm{Th}_{\mathrm{eq}}$ to the exposed rate at 1 meter above the ground and the cosmic radiation from a nearby site (Pascholati \& Amaral 1992). The parameters of the equation 2 take in to account the absorbed dose in air and the effective dose utilizing the indoor-outdoor occupancy factor (UNSCEAR 2000), where the numerical values vary with the age of the population and the local climate (Beamish 2006).

\section{Results and Discussion}

The airborne and ground data were interpolated by Minimum Curvature method (Briggs 1974), and the contour maps superimposed on the Digital Elevation Model (DEM) are presented in Figures 3 and 4. The shapefiles of both granitic bodies are from Mineropar (2006).

Analysis of Serra do Carambeí (CA) granite 
Potassium and uranium presented discrete values in the airborne data when compared with the respective crustal averages (Tab. 1). Highest contents of $\mathrm{K}$ occur on valleys and at bottom of slopes in the alkali feldspar granite (Fig. 3 ). This behavior is due to the effects of erosion, depletion, transport and deposition of $\mathrm{K}$ that cumulates in lowest zones and nearly downhills. In high altitude regions and low declivity, the concentration of $U$ is not expressive. This can be explained due the effect of percolation of the water in plane areas that acts in favor of lixiviation of rocks and transport of $\mathrm{K}$ and $\mathrm{U}^{+6}$. The high mobility of $\mathrm{K}$ explains the lower concentration on the top of CA granite. Concentration of $\mathrm{U}_{\mathrm{eq}}$ and $\mathrm{Th}_{\mathrm{eq}}$ are very similar and occur most part in the north and along the east, circulating and delimiting the body. Uranium and thorium are most located on the edges of the granite, but uranium particularly showed bigger area on south. In the greatest depressions, where ticker layers of sediments, organic matter and soil is present, the uranium concentration shows low (Fig. 3).

Table 1. Statistic radioactivity measurements of CA

\begin{tabular}{ccccccc}
\hline & \multicolumn{3}{c}{ Airborne } & \multicolumn{3}{c}{ Ground } \\
\hline & $\mathrm{K}$ & $\mathrm{U}_{\mathrm{eq}}$ & $\mathrm{Th}_{\mathrm{eq}}$ & $\mathrm{K}$ & $\mathrm{U}_{\mathrm{eq}}$ & $\mathrm{Th}_{\mathrm{eq}}$ \\
\hline samples & 766 & 766 & 766 & 84 & 84 & 84 \\
mean & 0.53 & 4.47 & 28.44 & 1.66 & 7.25 & 39.08 \\
median & 0.46 & 4.18 & 27.32 & 0.30 & 6.10 & 38.55 \\
std & 0.36 & 1.76 & 10.39 & 1.89 & 3.92 & 15.23 \\
min & 0.00 & 0.57 & 11.84 & 0.10 & 1.20 & 6.40 \\
$25 \%$ & 0.29 & 3.33 & 22.39 & 0.10 & 4.60 & 29.37 \\
$50 \%$ & 0.46 & 4.18 & 27.32 & 0.30 & 6.10 & 38.55 \\
$75 \%$ & 0.69 & 5.28 & 31.22 & 3.40 & 8.57 & 48.20 \\
max & 2.18 & 12.95 & 90.71 & 6.10 & 19.20 & 82.20 \\
\hline
\end{tabular}

Table 2. Statistic radioactivity measurements of JM

\begin{tabular}{ccccccc}
\hline & \multicolumn{3}{c}{ Airborne } & \multicolumn{3}{c}{ Ground } \\
\hline & $\mathrm{K}$ & $\mathrm{U}_{\mathrm{eq}}$ & $\mathrm{Th}_{\mathrm{eq}}$ & $\mathrm{K}$ & $\mathrm{U}_{\mathrm{eq}}$ & $\mathrm{Th}_{\mathrm{eq}}$ \\
\hline samples & 310 & 310 & 310 & 38 & 38 & 38 \\
mean & 1.86 & 4.36 & 17.13 & 3.8 & 9.22 & 40.68 \\
median & 1.31 & 3.46 & 10.88 & 4.65 & 6.65 & 29.35 \\
std & 0.60 & 1.24 & 8.37 & 2.36 & 8.10 & 37.98 \\
min & 1.10 & 2.23 & 7.46 & 0.10 & 1.40 & 8.90 \\
$25 \%$ & 1.37 & 3.47 & 10.34 & 1.02 & 5.25 & 22.17 \\
$50 \%$ & 1.72 & 4.27 & 14.32 & 4.65 & 6.55 & 29.35 \\
$75 \%$ & 2.16 & 5.02 & 22.42 & 5.77 & 8.60 & 37.50 \\
max & 3.50 & 8.10 & 49.76 & 7.50 & 38.00 & 161.50
\end{tabular}

It is must be noted that CA presented almost ten times more $\mathrm{Th}_{\mathrm{eq}}$ than the crust average. High concentration of $\mathrm{Th}_{\mathrm{eq}}$ and $\mathrm{U}_{\mathrm{eq}}$ occur with more frequency in areas of high elevation, but we verify a distribution of highest values across east and north. Therefore, as expected, the topography was not a decisive factor to the thorium behavior. On the other hand, we verify "hot" areas where the topographic gradient is accentuated, probably because in these parts, the rock is more expose and sediments or soils cannot mask the radiometric original response.
Ground and airborne data presented different spatial distribution patterns but compatible values (Fig. 3). In the ground data, the $\mathrm{K}$ mean is about four time higher than the airborne one $(0.53 \%-1.66 \%)$, while the maximum concentration of $U_{\text {eq }}$ increases by 6.25 ppm (12.95 - 19.20 $\mathrm{ppm})$. The maximum ground concentration of $\mathrm{Th}_{\mathrm{eq}}$ is 8.5 ppm lower than the airborne correspondent data (Fig. 2).
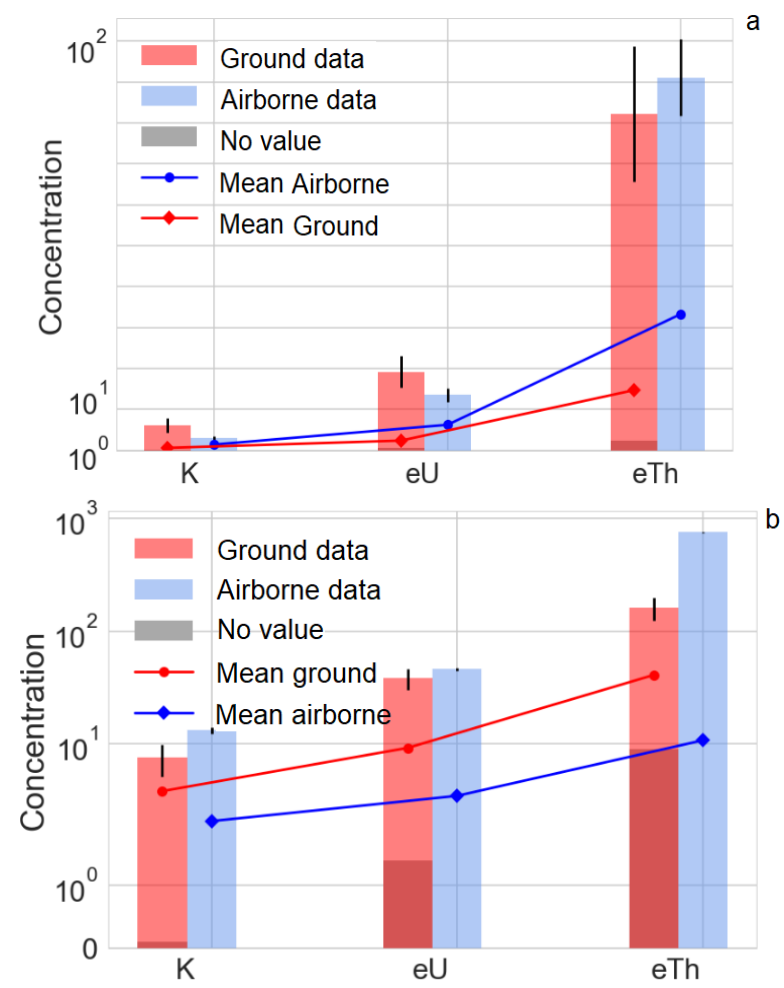

Figure 2- Graphs of $K, U_{e q}$ and $T h_{\text {eq }}$ concentration of (a) Serra do Carambeí and (b) Joaquim Murtinho granites. Black thin bars represent the standard deviation.

The mean estimates doses of AAD and AED are in the Table 3 and 4 . As we can see, the ground data is more disperse demonstrating the wide range of values acquired by this type of survey.

Table 3. Estimates of air absorbed dose (AAD)

\begin{tabular}{ccccc}
\hline Granite & & \multicolumn{3}{c}{$\mathrm{AAD}\left(\mathrm{nGy} \mathrm{h}^{-1}\right)$} \\
\hline \multirow{2}{*}{ Carambeí } & Type & Mean & std & Sample \\
\cline { 2 - 5 } & Airborne & 103.30 & 33.07 & 766 \\
\cline { 3 - 5 } Joaquim & Ground & 152.80 & 42.75 & 84 \\
Murtinho & Ground & 73.29 & 25.85 & 310 \\
& & 171.07 & 115.14 & 38 \\
\hline
\end{tabular}

Table 4. Estimates of annual effective dose (AED)

\begin{tabular}{ccccc}
\hline Granite & \multicolumn{3}{c}{ AED $\left(\mu\right.$ Sv $\left.y^{-1}\right)$} \\
\hline \multirow{2}{*}{ Carambeí } & Type & Mean & std & Sample \\
\cline { 2 - 5 } & Airborne & 972.65 & 225.21 & 766 \\
\cline { 1 - 4 } Joaquim & Ground & 285.31 & 383.54 & 84 \\
Murtinho & Airborne & 889.69 & 194.30 & 310 \\
& Ground & 1589.77 & 930.65 & 38 \\
\hline
\end{tabular}





data. The isolines of $1000 \mu S v y^{-1}$ are insert in the AED maps.

The maps of the AED of CA (Fig. $3 \mathrm{i}, \mathrm{j}$ ) and AAD (Fig. 3 g,h), shows that the annual effective doses are affected mainly by $\mathrm{U}_{\mathrm{eq}}$ and $\mathrm{Th}_{\mathrm{eq}}$ content, being thorium the major influence. The highest values of AED are seen in the east edge and north of the granitic body and in more elevated areas with values up to $2229 \mu \mathrm{Sv} \mathrm{y}^{-1}$ (airborne) and 2146 $\mu S v y^{-1}$ (ground). The highest values of AED are seen in the edge and north of the granitic body and in more elevated areas with values up to $2229 \mu \mathrm{Sv} \mathrm{y}^{-1}$ (airborne) and $2146 \mu \mathrm{Sv} \mathrm{y}^{-1}$ (Ground). The maps of AAD and AED have the same characteristics in terms of distribution. The data collected on ground present more dispersive pattern than that of collected on air. AAD showed mean values up the $100 \mathrm{nGy} \mathrm{h}^{-1}$ and a maximum of $300 \mathrm{nGy} \mathrm{h}^{-1}$ (Tab. 3, Fig. $4 \mathrm{~g}, \mathrm{~h}$ ), much higher than the $51 \mathrm{nGy}^{-1}$ recommended.

\section{Analysis of Joaquim Murtinho (JM) granite}

All three radioelements of the ground data processing showed anomalous high zones that overcome the crust average, but in the airborne data only Th revel elevated counting, reaching almost 200 ppm (Fig. 4). None of them shows strong correlation between the geophysical anomalies and topography, this means that the concentration of $\mathrm{K}, \mathrm{U}$ and Th seems more related to lithologic itself and the different facies of JM granite. Even so, it is possible to observe that the anomaly of $U$ and $T h$ set in the highest portion of the map whereas the K present a more fluid behavior, allocated and distributed on slopes with high gradient variation but near to the same $\mathrm{U}$ and $\mathrm{Th}$ anomaly. In the center (Fig. 4 a,b,c,d,e,f) strong anomalies of $\mathrm{U}_{\mathrm{eq}}$ and $\mathrm{Th}_{\mathrm{eq}}$ associated with depletion of $\mathrm{K}$, suggest an accentuated process of weathering. Highest values of Potassium concentrate in south-west and a small part in the south and center-east of JM. In general, the body present medium-strong $\mathrm{K}$, associated with the feldspathic quartz composition of the igneous rock. Uranium shows very low values in the east, where the topography is compost by valleys and abrupt slopes. The principal $U_{e q}$ anomaly (Fig. 4 c,d) covers the center-southeast of the JM granite. In same location, a strong anomaly of $\mathrm{Th}_{\mathrm{eq}}$ shows content around 35-50 ppm in the airborne data and about 100-200 ppm in the ground data (Fig. 4 e,f).

To all radioelements, from minimum to maximum and including the mean and median, the terrestrial data presented much higher values in comparison than airborne data (Tab.2, Figure 3).

The mean of AAD of JM in the terrestrial data was 100 nGy $\mathrm{h}^{-1}$ higher of that found in the airborne database, being the maximum 4 times higher. There was no measure below Again, Th influences more the AED distribution than potassium and uranium on both data type, being $T h$ responsible for the highest percentage. AED attained almost $1500 \mu \mathrm{Sv}^{-1}$ (airborne) and $4931 \mu \mathrm{Sv}^{-1}$ (ground) in the light pink spots. This difference between AED calculation is connected to the much higher reading of $\mathrm{Th}_{\mathrm{eq}}$ on ground when compared with the maximus content of the same element in the airborne data (Fig. 4 e,f), with maximum reading of $\mathrm{Th}_{\mathrm{eq}}$ overtaking $150 \mathrm{ppm}$ where the maximum is $50 \mathrm{ppm}$ in the aero survey data (Tab. 2). 



Figure 4 - JM gamma-ray spectrometric maps of $K$ (a), $U_{e q}$ (c), $T h_{e q}(e), A A D(g)$ and $A E D$ (i) from airborne data and $K$ (b), $U_{e q}$ (d), $T h_{e q}(f), A A D$ (h) and $A E D$ (j) from ground data. The isolines of $1000 \mu S v y^{-1}$ are insert in the AED maps.

\section{Conclusions}

Air absorbed dose (AAD) and annual effective dose (AED) radiation reached elevated values being the maximum reading of $A E D$ to both granites very high and worrying. The highest value of AED in the CA granite is more than twice the value recommended by IAEA, being $2229 \mu \mathrm{Sv}^{-1}$ (airborne) and $2146 \mu \mathrm{Sv}^{-1}$ (ground), with averages of 972 $\mu \mathrm{Sv}^{-1}$ (airborne) and $285 \mu \mathrm{Sv}^{-1}$ (ground). In the JM the AED obtained almost $1500 \mu \mathrm{Sv} \mathrm{V}^{-1}$ (airborne) and around
$5000 \mu \mathrm{Sv} \mathrm{y}^{-1}$ (ground), with averages of $889 \mu \mathrm{Sv} \mathrm{y}^{-1}$ (airborne) and $1589 \mu \mathrm{Sv} \mathrm{y}^{-1}$ (ground) while the AAD average in CA is $100 \%$ (airborne) and $170 \%$ (ground) above the recommended safety value and $35 \%$ (airborne) and $218 \%$ (ground) above in JM.

The Th seems to be the radioelement less affected by the weathering. The high measurements of $\mathrm{Th}_{\mathrm{eq}}$ influenced more the results of $A E D$ and $A A D$ than $K$ and $U_{\text {eq }}$.

The spatial distribution of $\mathrm{K}, \mathrm{Th}_{\mathrm{eq}}$ and $\mathrm{U}_{\mathrm{eq}}$ have been studied through airborne and terrestrial surveys. The ground data presented higher values than the aerial ones, probably due the different sampling types (point sampling versus field of view sampling, respectively), wind and because the radiation detected is stronger near the ground, suggesting that important attenuating processes could occurred in air between soil and detector. In addition, portion of gamma-ray flux must have been affected by variation on soil thickness, moisture, organic matter and lixiviation processes, so we cannot link the variation of doses only to the composition of the granitic rocks, since it is known the importance of soil characteristics to radiation ionization.

\section{Acknowledgements}

The authors are grateful to CPRM for provide the airborne radiometric data. $F$ Antonelli and FJF Ferreira were supported in this research by a fellowship from CAPES Foundation, Ministry of Education, Brazil and the National Council for Scientific and Technological Development (CNPq, Brazil) (contract 303826/2018-5), respectively. The authors thank O. A. de Souza Filho for the revision of the manuscript.

\section{References}

Beamish D. 2016. Mapping the terrestrial gamma radiation dose. in M.E. Young (ed.), Unearthed: impacts of the Tellus surveys of the north of Ireland. Dublin. Royal Irish Academy. 13 pp.

Beretka J, Matthew PJ. 1985. Natural Radioactivity of Australian Building Materials, Industrial Wastes and ByProducts. Health Physics, 48, 87-95.

CCGP - Comissão da Carta Geológica do Paraná, 1970. Folha Geológica Jaguariaíva-Sul, 1:70.000. Curitiba, CCGP.

CPRM - Serviço Geológico do Brasil 2011. Projeto Aerogeofísico Paraná - Santa Catarina: relatório final do levantamento e processamento dos dados magnetométricos e gamaespectrométricos. Lasa prospecções, 326p.

Dickson BL, Scott KM. 1997. Interpretation of aerial gamma-ray surveys adding the geochemical factors. AGSO Journal of Australian Geology and Geophysics, 17(2), 187-200.

EC - European Commission. Radiological Protection 1999. Principles concerning the Natural Radioactivity of Building materials, Radiation Protection Report RP-112, Luxembourg. 
Engola LN, Nkoulou II JEN, Hosoda M, Bongue D, Saidou, Akata N, Heya RK, Njock MGK, Tokonami S. 2018. Air Absorbed Dose Rate Measurements and External Dose Assessment by Car-Borne Survey in the Gold Mining Areas of Betare-Oya, Eastern-Cameroon. Jpn. J. Health Physics, 53 (1), 200-209.

Ferreira FJF, Riffel SB, Forlin M, Guimarães GB. 2001. Gamaespectrometria do Granito Serra do Carambeí-PR. In: VII Congresso Internacional da Sociedade Brasileira de Geofísica - SBGF, 2001, Salvador. Anais, SBGF, 2001.

Frutchting A, Guimarães GB, Ferreira FJF, Ulbrich HHGJ. 2003. Gamaespectrometria do granito Joaquim Murtinho, Complexo Granitóide Cunhaporanga (PR). SBGF, 8th International Congress of The Brazilian Geophysical Society.

Godoy L, Bittencurt AVL, Santos LJC, Ferreira FJF. 2011. Distribuição de K, eU e eTh e avaliação da dose anual de radiação na região do granito Serra do Carambeí. Brazilian J. of Geophysics - RBGF, 29(2), 359-375.

Grasty RL, Carson JM, Charbonneau BW, Holman PB. 1984. Natural Background radiation in Canada. Geological Survey of Canada. Bulletin 360. 39p.

Grastly RL, LaMarre JR. 2004. The annual effective dose from natural sources of ionising radiation in Canada. Radiation protection dosimetry, 108 (3), 215-226.

Guimarães GB 1995. O Complexo Granítico Cunhaporanga na região de Joaquim Murtinho, Piraí do Sul (PR): caracterização faciológica das rochas granitóides. Dissertação de Mestrado em Geociências (Mineralogia e Petrologia) - Universidade de São Paulo, $144 p$.

Guimarães GB. 2000. As Rochas granitóides do complexo granítico Cunhaporanga, Paraná: Aspectos geológicos geofísicos, geoquímicos e mineralógicos. Tese de Doutorado do Instituto de Geociências da Universidade de São Paulo -USP, 337p.

Guimarães GB, Ulbrich HHGJ. 1996. Redefinição e tipologia do Granito Joaquim Murtinho, Piraí do Sul (PR). In: XXXIX Congresso Brasileiro de Geologia, 1996, Salvador, BA. Anais. Salvador: SBG-BA, (6), 367-369.

HPA - Health Protection Agency. Radon and Public Health 2009. Report of the independent Advisory Group on Ionizing Radiation. 240p.

IAEA - International Atomic Energy Agency 1991. Airborne gamma ray spectrometry surveying. Technical Report Series 323. Vienna.

IAEA - International Atomic Energy Agency 2003. Method for Developing Arrangements for Response to a Nuclear or Radiological Emergency. Annual report IAEA-TECDOC953, $269 \mathrm{p}$.

IAEA - International Atomic Energy Agency 2010. Radioelement Mapping Nuclear Energy Series, No. NF-T1.3. Vienna.

ICRU - International Commission on Radiation Unit and Measurements 1994. Gamma ray spectrometry in the environment. ICRU Report 53.
Mineropar - Instituto de Terras, Cartografia e Geologia do Paraná 2006. Curitiba (PR): Mapa Geológico do Paraná, escala 1:250.000.

Oatway WB, Jones AL, Holmes S, Watson S, Cabianca T. 2016. lonising Radiation Exposure of the UK Population: 2010 Review. PHE-CRCE-026, 48p.

Pascholati EM, Amaral G. 1992. Avaliação de níveis de radiação ambiental natural a partir de gamaespectrometria de campo. XXXVII Congresso Brasileiro de Geologia SBG, São Paulo, 1992.

Pinto-Coelho CV. 1986. O granito Serra do Carambaí-PR e as anomalias uraníferas associadas. Tese de mestrado do Instituto de Geologia da Universidade de Brasília UNB, 340p.

Ulbrich HHGJ, Ferreira FJF, Guimarães GB. 2009. Gamma-spectrometric Surveys in Differentiated Granites. I: A review of the method, and of the geochemical behavior of K, Th and U. Geol. USP Sér. Cient., São Paulo, v. 9 (1), 33-53.

UNSCEAR - United Nations Scientific Committee on the Effects of Atomic Radiation - UNSCEAR. 2000. Vol 1: Sources. 82p.

UNSCEAR - United Nations Scientific Committee on the Effects of Atomic Radiation - UNSCEAR. 2010. Report to the General Assembly with scientific annexes: United Nations, New-York, 65p.

US EPA - U.S. Environmental Protection Agency, Office of Air and Radiation Indoor Environments Division 1993. Radon-A Physician's Guide: The health threat with a simple solution. Solar-Terr. Phys., 59, 1225-1232.

NEA-OECD - Nuclear Energy Agency 1979. Exposure to Radiation from natural radioactivity in building materials. Report by group of experts of the OECD (NEA), $44 \mathrm{pp}$.

Wilford JR, Bierwirth PN, Craig MA. 1997. Application of airborne gamma-ray spectrometry in soi/regolith mapping and applied geomorphology. AGSO, J. of Australian Geology and Geophysics, 17(2), 201-2016.

Ye R, Gan N. 2013. Estimation of terrestrial air-absorbed dose rate from the data of regional geochemistry database. J. of Nuclear Science and Technology, 51(3), 405-412. 